\title{
POLITISASI KEBIJAKAN DALAM RANCANGAN UNDANG-UNDANG KEAMANAN NASIONAL
}

\author{
Yusa Djuyandi \\ Marketing Communication Department, Faculty of Economic and Communication, BINUS University \\ Jln. K.H. Syahdan No.9 Palmerah, Jakarta Barat 11480 \\ yusa@binus.ac.id
}

\begin{abstract}
Discussion of the draft of National Security Act in the House of Representatives cannot be separated from the political charge. Politicization of policy formulation in the draft of National Security Act sometimes can lead to the policy distortion. The purpose of this study is to describe and analyze the policy politicization of National Security Act draft. This study revealed that from the aspect of "all questions political questions", the Parliament gives a political question in the framework of the process of policy control. In the second aspect, "all issues political issues", issues that arise and become a concern are issues which are considered threaten the human rights and democracy. In the third, "all values political values", the parliament is fighting for the human rights and democracy values. From the last aspect of "all decisions political decisions", the parliament political decision for not approving the draft, because it is not in favor with the agenda of reformation and democracy. This study concluded that the politicization of policy in the Draft Law is still considered normal. Politicization occurred because policy adoption involves the executive and the legislature, in the context of political checks and balances.
\end{abstract}

Keywords: national security, policy politicization, democracy, human rights

\begin{abstract}
ABSTRAK
Pembahasan Rancangan Undang-Undang Keamanan Nasional di Dewan Perwakilan Rakyat tidak terlepas dari adanya muatan politik. Politisasi kebijakan dalam perumusan Rancangan Undang-Undang Keamanan Nasional meskipun tidak selalu berdampak negatif, terkadang dapat menimbulkan distorsi terhadap kebijakan yang akan dihasilkan. Tujuan penelitian ini adalah untuk mendeskripsikan dan menganalisis terjadinya politisasi kebijakan dalam Rancangan Undang-Undang Keamanan Nasional. Metode penelitian yang digunakan adalah metode kualitatif dengan data penelitian primer dan sekunder. Data primer dilakukan melalui teknik observasi dan wawancara. Hasil dan Pembahasan mengungkapkan bahwa dari aspek semua pertanyaan menjadi pertanyaan politik, DPR memberikan pertanyaan politik dalam rangka proses pengawasan kebijakan. Dari aspek isu-isu politik, isu yang muncul dan menjadi perhatian adalah isu yang dianggap mengancam Hak Asasi Manusia dan demokrasi. Dari aspek semua nilai menjadi nilai politik, yang diperjuangkan adalah nilai HAM dan demokrasi. Sedangkan dari aspek keputusan politik, keputusan politik DPR belum mengesahkan rancangan undang-undang karena rancangan kebijakan itu belum berpihak pada agenda reformasi dan demokrasi. Simpulan penelitian ini adalah politisasi kebijakan Rancangan Undang-Undang Keamanan Nasional masih dalam kewajaran. Politisasi kebijakan juga wajar terjadi karena pengesahan kebijakan melibatkan lembaga eksekutif dan legislatif, dalam rangka pemeriksaan dan keseimbangan politik.
\end{abstract}

Kata kunci: keamanan nasional, politisasi kebijakan, demokrasi, Hak Asasi Manusia 


\section{PENDAHULUAN}

Pertahanan dan keamanan adalah dua konteks yang berbeda namun keduanya saling mendukung dalam menciptakan kondisi yang stabil, aman dan tertib. Tanpa ada keduanya maka suatu negara dan bangsa akan sulit untuk mempertahankan integritasnya sebagai suatu bangsa yang merdeka dan berdaulat. Tentara Nasional Indonesia (TNI) selaku aktor pertahanan dan Kepolisian Negara Republik Indonesia (POLRI) selaku aktor keamanan pada masa orde baru dilebur menjadi satu dalam Angkatan Bersenjata Republik Indonesia (ABRI). Hal ini dilakukan untuk menangkal adanya ancaman dari Partai Komunis Indonesia (PKI). Akan tetapi, peleburan ini juga yang memberikan dampak negatif terhadap institusi kepolisian Indonesia. Polisi menjadi makin militerisitis dengan bertindak represif terhadap aksi demonstrasi warga sipil.

Jatuhnya kekuasaan pemerintahan orde baru yang kemudian berganti dengan pemerintahan era reformasi memberikan dampak yang cukup positif bagi kehidupan politik bangsa Indonesia, reformasi di sektor pertahanan dan keamanan diawali dengan keluarnya kebijakan berupa TAP MPR Nomor VI Tahun 2000 yang memisahkan institusi TNI dan Polri. Kemudian dalam TAP MPR lainnya yaitu TAP MPR Nomor VII Tahun 2000 diatur dengan jelas peran TNI dan POLRI, yaitu TNI mengurus pertahanan negara dan Polri mengurus keamanan dalam negeri.

Reformasi sektor pertahanan dan keamanan tidak dapat berjalan dengan baik jika tidak didukung oleh reformasi legislasi. Oleh karena itu DPR bersama dengan pemerintah kemudian mendorong lahirnya undang-undang sektor pertahanan dan keamanan yang reformis seperti UU No. 2 Tahun 2002 tentang Kepolisian Negara Republik Indonesia, UU No. 3 Tahun 2002 tentang Pertahanan Negara, dan UU No. 34 Tahun 2004 tentang Tentara Nasional Indonesia (TNI). Terlepas dari sudah adanya UU POLRI, TNI, dan Pertahanan Negara, pemerintah dan DPR hingga saat ini belum mengesahkan Rancangan Undang-Undang (RUU) Keamanan Nasional (Kamnas) sebagai kebijakan yang akan menaungi sektor pertahanan dan keamanan.

RUU Keamanan Nasional merupakan sebuah rancangan kebijakan yang bertujuan untuk memperkuat reformasi dan proses demokrasi di Indonesia. Perumusan RUU Kamnas juga bagian yang tidak terpisahkan dari program legislasi nasional di sektor pertahanan dan keamanan. Kebijakan keamanan nasional dibutuhkan agar bangsa Indonesia mempunyai acuan yang jelas dalam mendefinisikan ancamanan keamanan dan pertanahan, mengorganisasikan aparatur negara untuk mengatasi masing-masing ancaman yang berbeda, proses penanggulangan ancaman, serta proses koordinasi antarinstitusi.

Pada saat Indonesia membutuhkan adanya kejelasan dalam membangun suatu sistem keamanan nasional yang terpadu dalam sebuah RUU Kemanan Nasional (Kamnas), di sisi lain terjadi pertentangan dalam mendefinisikan pertahanan dan keamanan baik dari aktor pertahanan dan keamanan itu sendiri (TNI dan POLRI) maupun oleh beberapa aktor politik di Dewan Perwakilan Rakyat (DPR) dengan pemerintah. Sebagian dari unsur kepolisian beranggapan bahwa draft RUU Kamnas dapat mengakibatkan tumpang tindihnya peranan antara TNI dan POLRI. Fuad (2012) menuliskan Irjen Pol (Purn) Sisno Adiwinoto menilai, beleid ini bisa membuat kewenangan polisi dan tentara saling tumpang tindih. Berbeda halnya dengan sebagian anggota DPR yang berpandangan substansi beberapa pasal dalam draft RUU tersebut bersifat sensitif karena didalamnya terdapat isu-isu sensitif seperti soal hak asasi manusia.

Munculnya perbedaan pendapat dalam pembahasan RUU Kamnas merupakan sebuah hal yang wajar, namun berlarut-larutnya pembahasan draft kebijakan tersebut dapat dianggap sebagai sesuatu hal yang tidak wajar. Perlu diketahui bahwa draft RUU Kamnas sudah masuk dalam proses legislasi nasional (prolegnas) 2004-2009, tetapi hingga 2012 kebijakan tersebut belum disahkan. Hambatan 
dalam penyusunan RUU Kamnas dapat berarti juga hambatan bagi jalannya proses reformasi sektor keamanan. Terjadinya tarik ulur kepentingan antarpihak mencerminkan rumitnya perumusan kebijakan ini secara politik.

Pembahasan RUU Kamnas di DPR sebagai suatu kebijakan pada prinsipnya juga tidak terlepas dari adanya muatan-muatan politik. DPR merupakan lembaga negara yang merupakan representasi dari beberapa partai politik. Sedangkan masing-masing Parpol memiliki kepentingan dan ideologi yang berbeda. Dalam sebuah negara demokrasi keterlibatan DPR diperlukan dalam menyusun kebijakan negara. Terlebih DPR merupakan lembaga negara yang fungsi utamanya adalah membuat undang-undang (Joyce, 2008) meskipun terkadang kepentingan politik terdapat didalam pembuatan undang-undang.

Politisasi kebijakan, meskipun tidak selamanya berdampak negatif, terkadang menimbulkan distorsi atau penyimpangan terhadap kebijakan yang akan dihasilkan. Begitu pun hal-hal yang terkait dengan politisasi kebijakan di bidang pertahanan dan keamanan. Akibat yang terlihat dalam pembahasan RUU Kamnas adalah adanya perdebatan di ruang publik yang hanya terbatas pada substansi tentang: gradasi keadaan bahaya/darurat yang memunculkan kekhawatiran tentang pasal kudeta; pengaturan kewenangan politik dan operasional yang menghadirkan polemik tentang posisi Polri dalam sistem ketatanegaraan Indonesia; pelibatan aktor keamanan nasional yang mempertanyakan pelibatan TNI untuk masalah-masalah keamanan nasional; koordinasi TNI, Polri dan keberadaan aktor intelijen dalam penanggulangan ancaman; dan persoalan komponen cadangan yang memunculkan kekhawatiran terhadap lahirnya wajib militer bagi warga sipil. Maka dari itu, pembahasan RUU Kamnas memang dinilai oleh sebagian kalangan masyarakat bersifat kontroversial termasuk dari beberapa kalangan di kepolisian.

Berdasarkan fenomena yang telah diuraikan, rumusan masalah penelitian adalah tentang politisasi kebijakan dalam Rancangan Undang-Undang (RUU) Keamanan Nasional. Dari rumusan masalah tersebut kemudian ditentukan tujuan dan manfaat penelitian. Penelitian bertujuan untuk mendeskripsikan dan menganalisis terjadinya politisasi kebijakan dalam Rancangan Undang-Undang (RUU) Keamanan Nasional. Sedangkan manfaat atau kegunaan hasil penelitian dapat diklasifikasikan menjadi manfaat teoretis dan manfaat praktis sebagai berikut. Secara teoretis, penelitian ini diharapkan dapat bermanfaat bagi pengembangan ilmu pengetahuan, khususnya yang terkait dengan ilmu politik. Secara praktis, penelitian diharapkan menjadi sarana belajar untuk mengintegrasikan pengetahuan dan kemampuan dalam kebijakan politik, khususnya terkait dengan politisasi kebijakan.

\section{Landasan Teori}

\section{Politisasi}

Politisasi kebijakan atau perundang-undangan, terutama dalam praktik, terkadang menimbulkan suasana tidak menentu (Sadono, 2010). Pengertian politisasi bermuara kepada definisi Ilmu Politik. Ilmu Politik menurut Budiardjo (2009) adalah sebuah ilmu yang mempelajari politik sebagai usaha menggapai kehidupan yang lebih baik. Untuk menggapai kehidupan masyarakat yang lebih baik diperlukan adanya kekuasaan yang melaluinya dapat dibuat kebijakan yang mengikat seluruh warga negara. Politik sebagai sebuah ilmu juga adalah seni yang menyangkut serangkaian aktivitas untuk memperoleh, menjalankan, dan mempertahankan kekuasaan untuk kebaikan masyarakat. Hal ini merujuk kepada pedapat Merkl (1967:13): "Politics, as its best is a noble quest for a good order and justice."

Dalam tataran ideal, menurut Surbakti (2010), berpolitik adalah membicarakan dan merumuskan tujuan-tujuan yang hendak dicapai dan ikut serta dalam upaya mengejar tujuan bersama. 
Akan tetapi, belakangan politik selalu diartikan sebagai sebuah kegiatan yang kotor. Hal ini disebabkan serangkaian aktivitas politisi yang selalu mengatasnamakan rakyat untuk memperoleh kekuasaan atau melegalkan kebijakan yang mereka buat namun sangat jarang memerhatikan kepentingan rakyat. Perilaku aktor politik yang mengedepankan kepentingan pribadi dan golongan merupakan sifat yang tidak terpuji dan merupakan bentuk aktivitas politik yang paling buruk. Merkl (1967:13) mengungkapkan: "Politics as its worst is a selfish grab for power, glory and riches."

Politisasi menurut Kamus Besar Bahasa Indonesia (2014) berarti hal membuat keadaan (perbuatan, gagasan, dsb) bersifat politis. Dengan kata lain, politisasi itu adalah segala bentuk tindakan, baik melalui gagasan atau perbuatan yang bersifat seperti cara menghadapi maupun memperoleh kekuasaan dan atau kebijaksanaan (politis). Definisi politisasi memiliki makna yang luas karena dapat memasuki berbagai bidang yang berbeda dalam segala aspek kehidupan masyarakat dan pemerintahan. Peters dan Pierre (2004:3) mendefinisikan politisasi sebagai: "politicization may also mean that public servants begin to take on tasks that formerly (and formally) might have been considered to be political.” Sedangkan Martini (2010) mendefinisikan politisasi sebagai membuat atau mengupayakan agar sesuatu sesuai dengan kepentingannya. Sementara Richard M. Ebelin sebagaimana dikutip Erdogan (2004:9) mengemukakan "Politicization can be defined as that now pervasive tendency for making all questions political questions, all issues political issues, all values political values, and all decisions political decisions."

Dari berbagai definisi dan konsep tentang politisasi, dapat dikatakan bahwa politisasi merupakan sebuah proses memasukkan hal-hal yang bersifat politik ke berbagai aktivitas yang menyangkut urusan publik. Politisasi dapat berdampak negatif jika dilatarbelakangi kepentingan individu dan kelompok.

\section{Kebijakan}

Kebijakan menurut Budiardjo (2009) adalah suatu kumpulan keputusan yang diambil oleh seorang pelaku atau kelompok politik, dalam usaha memilih tujuan dan cara untuk mencapai tujuan itu. Dari hal yang dikemukakan Budiardjo, nampak aktivitas politik juga memiliki keterkaitan dengan aktivitas yang dilakukan dalam rangka pembuatan kebijakan.

Kebijakan dibuat untuk ditaati dan dilaksanakan seluruh anggota masyarakat sehingga kebijakan dapat diartikan sebagai suatu produk hukum. Dalam hal ini Nugroho (2004:3) mengemukakan: “Adalah benar bahwa suatu kebijakan merupakan hukum.” Pendapat serupa dikemukakan Friedrick (dalam Nugroho, 2004:4), yang mendefiniskan kebijakan:

"Serangkaian tindakan yang diusulkan seseorang, kelompok atau pemerintah dalam suatu lingkungan tertentu, dengan ancaman dan peluang yang ada, dimana kebijakan yang diusulkan tersebut ditujukan untuk memanfaatkan potensi sekaligus mengatasi hambatan yang ada dalam rangka mencapai tujuan tertentu."

Kebijakan publik diartikan sebagai suatu produk hukum diperkuat juga oleh Nogi, dkk. (2004:6): "Bahwa sesungguhnya produk hukum yang ada, pada dasarnya adalah hasil dari kebijakan publik yang melewati proses formulasi kebijakan dimana telah dipilih alternatif-alternatif tindakan yang harus dilakukan pemerintah.”

Berdasarkan pandangan tersebut, RUU Kamnas merupakan sebuah rancangan kebijakan yang jika kelak disahkan DPR dan Presiden untuk menjadi Undang-Undang akan menjadi sebuah kebijakan yang berstatus hukum dan mempunyai kekuatan hukum yang mengikat seluruh warga negara. Rancangan kebijakan ini memiliki sifat yang sangat penting dan mendasar maka banyak pihak yang kemudian berkepentingan dengan rancangan kebijakan ini. Menurut Islamy (2004:13) "Pengertian 
kebijakan mencakup aturan-aturan yang ada di dalamnya, sedangkan kebijaksanaan memerlukan pertimbangan-pertimbangan yang lebih menekankan kearifan seseorang.”

Anderson (dalam Sunggono, 1994:14) merumuskan kebijakan sebagai a purposive course of action followed by an actor or set of actors in dealing with a problem or matter of concern. Sama halnya dengan pendapat Anderson, RUU Kamnas mempunyai tujuan tertentu yaitu untuk mendefinisikan dan mengatur berbagai hal dalam ruang lingkup pertahanan dan keamanan. Yang kemudian hal tersebut diikuti dan dilaksanakan pelaku atau sekelompok pelaku yang disebutkan dalam undang-undang guna memecahkan suatu masalah tertentu dalam ruang lingkupnya. Sedangkan Winarno (2008:31) mendefiniskan kebijakan sebagai arah tindakan yang mempunyai suatu tujuan yang diambil oleh seorang aktor atau sejumlah aktor dalam mengatasi suatu masalah atau persoalan.

Seperti telah diuraikan, bahwa kajian mengenai kebijakan tidak akan terlepas dari keterlibatannya dengan pemerintah, baik sebagai administrator, aktor maupun pelaku kebijakan itu sendiri. Banyak ahli mengemukakan pengertian kebijakan pemerintah atau kebijakan negara sebagai terjemahan dari public policy yang mana mereka cenderung menyamakan kebijakan publik dengan tindakan-tindakan yang dilakukan oleh pemerintah. Jika ditinjau dari sudut etimologis, dapat diartikan atau diterjemahkan bahwa public policy adalah kebijakan publik, kebijakan umum, kebijakan negara, kebijakan pemerintah, kebijakan terbuka, dan lain-lain. Akan tetapi secara terminologis kecendrungan penggunaan public policy dalam bahasa Indonesia diterjemahkan menjadi kebijakan pemerintah.

Edwards III dan Sharkansky (dalam Islamy, 2004:18) mengartikan kebijakan negara sebagai "...what governments say and do, or do not do. It is the goals or purposes of government programs." Seorang ahli lainnya, Udoji (dalam Wahab, 2004:5), mendefinisikan kebijakan pemerintah sebagai: "Kebijakan pemerintah sebagai suatu tindakan bersanksi yang mengarah pada suatu tujuan tertentu, diarahkan pada suatu masalah tertentu yang saling berkaitan serta mempengaruhi sebagaian besar warga masyarakat.”

Pengertian dalam perspektif yang berbeda mengenai kebijakan pemerintah dikemukakan oleh Easton seperti dikutip Islamy (2004:19): "The authoritative allocation of values for the whole society." Adapun Laswell seperti dikutip Nugroho (2004:4) mendefinisikan kebijakan publik sebagai "suatu program yang diproyeksikan dengan tujuan-tujuan tertentu, nilai-nilai tertentu dan praktek-praktek tertentu.”

\section{Keamanan Nasional}

Konsep tentang keamanan nasional yang merupakan konsep umum dari pertahanan. Keamanan nasional (National Security) merupakan sebuah permasalahan yang sangat kompleks. Istilah nasional (national) mengandung makna yang luas, tidak hanya mencakup negara sebagai subjek maupun objek tunggal, tetapi juga melingkupi berbagai entitas yang ada di dalamnya. Secara etimologis, konsep keamanan (security) berasal dari bahasa latin securus (se + cura), yang memiliki makna terbebas dari bahaya, terbebas dari ketakutan (free from danger, free from fear). Kata ini juga dapat bermakna dari gabungan kata se yang berarti tanpa (without) dan curus yang berarti kesulitan (uneasiness). Jika digabungkan, kata tersebut akan bermakna "kebebasan dari kesulitan, atau sebuah situasi damai tanpa bahaya atau ancaman" (liberation from uneasiness or a peaceful situation without any risk or threat) (Prihatono, dkk., 2007).

Menurut La Ode "Konsep National Security lebih memuat makna yang mencakup penanggulangan atas ancaman bagi kelangsungan hidup negara, baik yang datang dari dalam maupun dari luar" (La Ode, 2006: 46). Apa yang dikemukakan oleh La Ode tentang adanya ancaman dari dalam dan dari luar akan membantu kita untuk membagi keamanan nasional ke dalam dua makna, yaitu makna antara keamanan (untuk ancaman dari dalam) dan pertahanan (untuk ancaman dari luar). 
Sedangkan pengertian keamanan nasional menurut Mahfudz, terfokus pada dua variabel, yaitu: pertama, penanggulangan ancaman kehidupan langsung hidup negara yang datang dari dalam negeri (keamanan); kedua, penanggulangan ancaman kehidupan langsung hidup negara yang datang dari luar negeri (pertahanan) (La Ode, 2006). Adapun Laksada TNI (Purn.) Wahyono SK mengatakan bahwa keamanan nasional adalah fungsi dan sekaligus kondisi tegaknya kedaulatan dan hukum negara, terjaminnya kelangsungan hidup bangsa dan negara serta perikehidupan rakyat, masyarakat dan pemerintah dalam skala nasional dan internasional (La Ode, 2006).

Walaupun konsep keamanan nasional (National Security) dapat dibedakan antara han(pertahanan) dan -kam (keamanan), dalam implementasi terbuka kemungkinan terjadinya tumpang tindih (overlap) penanganan atau kekosongan penanganan antara TNI dan POLRI. Menurut Mahfudz dalam La Ode (2006) terjadinya tumpang tindih penanganan antara TNI dan POLRI disebabkan masing-masing institusi tersebut merasa bertanggung jawab; atau sebaliknya, malah tidak bertanggung jawab. Adapun pertahanan adalah sebagai bagian dari keamanan nasional. Andi Widjajanto menyebutkan: "pertahanan negara adalah segala usaha untuk mempertahankan kedaulatan negara, keutuhan wilayah negara, dan keselamatan segenap bangsa dari ancaman dan gangguan terhadap keutuhan bangsa dan negara” (Bakrie, 2007:49). Pengertian yang tidak jauh berbeda tentang pertahanan juga dikemukakan oleh Suryohadiprojo (2005). Ia menyebutkan pertahanan negara adalah sistem keamanan terhadap kegiatan yang bersumber kekuatan luar negeri dan umumnya bersifat serangan dengan kekuatan militer oleh negara lain (Suryohadiprojo, 2005).

Berdasarkan peraturan perundang-undangan, yaitu Pasal 1, UU No. 34 Tahun 2004 tentang Tentara Nasional Indonesia, yang dimaksudkan dengan pertahanan negara adalah:

"Pertahahanan negara adalah segala usaha untuk menegakkan kedaulatan negara, mempertahankan keutuhan wilayah Negara Kesatuan Republik Indonesia, dan melindungi keselamatan segenap bangsa dari ancaman dan gangguan terhadap keutuhan bangsa dan negara, disusun dengan memperhatikan kondisi geografis Indonesia sebagai negara kepulauan."

Berangkat dari definisi tentang pertahanan, kemudian lahirlah sebuah konsep pertahanan dengan masing-masing negara memiliki konsep pertahanan nasional masing-masing. Adapun konsep pertahanan nasional Indonesia yang dikemukakan oleh La Ode (2006: 47) adalah: menghancurkan dan melumpuhkan musuh di wilayahnya sendiri; melumpuhkan musuh dalam perjalanan menuju Indonesia; menghancurkan atau melumpuhkan musuh di ambang pintu masuk wilayah perairan dan wilayah udara NKRI; menghancurkan atau melumpuhkan musuh jika musuh berhasil masuk wilayah perairan dan wilayah udara NKRI; menghancurkan atau melumpuhkan musuh jika musuh berhasil mengadakan aksi-aksi pendaratan; menghancurkan atau melumpuhkan musuh jika musuh berhasil menduduki sebagian wilayah daratan milik NKRI dengan serangan balasan yang menentukan.

Pada dasarnya konsep pertahanan nasional harus disertai juga dengan pembangunan sistem pertahanan negara yang disesuaikan dengan kondisi dan karakter bangsa. Hal ini, sebagaimana dikemukakan Anwar (2004) sangat berkaitan dengan sejarah nasional, kondisi geografis dan masalah kependudukan di Indonesia. Dari hal tersebut kemudian dapat dikatakan bahwa secara umum upaya pengembangan sistem pertahanan negara di Indonesia harus memerhatikan tiga faktor utama (Bakrie, 2007:12), yaitu: faktor geo strategis (baik internal maupun ekternal), faktor perubahan internasional, dan faktor gelar operasi militer guna memenangkan perang.

\section{METODE}

Penelitian dilakukan melalui teknik observasi dan wawancara. Data yang dikumpulkan terdiri dari data primer, yaitu dari informan dan observasi, serta data sekunder di lapangan. Untuk itu desain 
penelitian ini menggunakan metode kualitatif. Metode penelitian dipilih dan dianggap tepat karena metode kualitatif relevan dan cocok dengan masalah penelitian yang diajukan melalui interpretasi proses dan makna.

Sumber data ini terbagi menjadi dua jenis sumber data yaitu sumber data primer dan sekunder. Data primer merupakan data yang diperoleh secara langsung melalui observasi di lapangan dan wawancara dengan informan. Data sekunder yang dijaring adalah melalui studi dokumentasi, yaitu data yang diperoleh melalui dokumentasi yang relevan dengan penelitian ini. Informan yang dipilih adalah para pengamat di bidang pertahanan dan keamanan, serta Anggota Komisi III (Bidang Keamanan) Dewan Perwakilan Rayat Republik Indonesia. Sedangkan sumber data sekunder dalam penelitian ini adalah Rancangan Undang-Undang Keamanan Nasional, notulensi rapat, pedoman umum, hasil studi dari berbagai litelatur dan penelitian-penelitian terdahulu yang relevan.

Adapun alat bantu yang digunakan dalam penelitian ini berupa daftar wawancara sebagai uraian lebih lanjut dari pertanyaan penelitian, pedoman observasi, dan dokumentasi. Teknik ini dipilih untuk memberi kemudahan dalam kegiatan penelitian tidak dimaksudkan untuk membatasi tingkat fleksibilitas peneliti sebagai instrumen di lapangan. Wawancara dilakukan dengan para pengamat di bidang pertahanan dan keamanan, serta Anggota Komisi III (Bidang Keamanan) Dewan Perwakilan Rayat Republik Indonesia. Observasi dilakukan terhadap pembahasan atau diskusi Rancangan Undang-Undang Keamanan Nasional, notula, pedoman umum, hasil studi dari berbagai litelatur dan penelitian terdahulu yang relevan. Lebih lanjut, proses pengumpulan data pada penelitian ini disesuaikan dengan jenis penelitian. Data yang dihimpun dalam penelitian ini, yaitu berupa kata-kata, tindakan, dokumen, situasi, dan peristiwa yang dapat diobservasi. Sumber data yang dimaksud adalah kata-kata diperoleh secara langsung atau tidak langsung melalui observasi dan wawancara dan dokumen berupa catatan kegiatan yang tersimpan dalam dokumentasi.

Pengujian keabsahan data dalam penelitian ini didasarkan pada kriteria tertentu, yaitu derajat kepercayaan dan kebenaran data (credibility) yang diperoleh dari informan-informan yang terlibat dalam pembahasan RUU Keamanan Nasional, kebenaran (correctness) suatu deskripsi, simpulan, dan penjelasan (explanation) yang dapat diketahui dari kesesuaian dengan peraturan perundangan serta naskah/dokumen penting lainnya.

\section{HASIL DAN PEMBAHASAN}

Mengacu pada pandangan Winarno (2008:31) yang mendefiniskan kebijakan sebagai "arah tindakan yang mempunyai suatu tujuan yang diambil oleh seorang aktor atau sejumlah aktor dalam mengatasi suatu masalah atau persoalan”, kebijakan Rancangan Undang-Undang (RUU) Keamanan Nasional pada awal dirumusakannya bertujuan untuk mengatasi permasalahan di sektor keamanan nasional, khususnya dalam mendukung proses reformasi sektor pertahanan dan keamanan. Namun pembahasan kebijakan tersebut makin berlarut sejak dirumuskannya pada proses legislasi nasional (Prolegnas) 2004-2009. Berbagai kepentingan masuk dari berbagai unsur yang ada, baik pemerintah dan DPR maupun aktor pertahanan dan keamanan itu sendiri.

Politisasi kebijakan adalah persoalan yang kemudian muncul dalam perumusan kebijakan RUU Keamanan Nasional. Sebab hingga saat ini terjadi tarik ulur yang berujung pada belum disahkannya RUU Keamanan Nasional menjadi Undang-Undang. Di tengah harapan tercapainya solusi dalam mengatasi masalah pertahanan dan keamanan permasalahan lain muncul, belum tercapainya kesepakatan dalam proses pengesahan kebijakan keamanan nasional dapat mengakibatkan reformasi sektor pertahanan dan keamanan berjalan di tempat. Tidak selesainya pembahasan RUU Kamnas merupakan permasalahan serius yang dapat mengakibatkan perenggutan kebebasan masyarakat dalam demokrasi. 
Berdasarkan pandangan Ebelin sebagaimana dikutip oleh Erdogan (1997:9) "Politicization can be defined as that now pervasive tendency for making all questions political questions, all issues political issues, all values political values, and all decisions political decisions." Penelitian mendapatkan empat hal yang menjadi indikator dalam politisasi sebuah kebijakan, yaitu ketika terdapat kecenderungan yang meluas untuk membuat semua pertanyaan menjadi pertanyaan politik, semua masalah menjadi masalah politik, semua nilai menjadi nilai politik, dan semua keputusan menjadi keputusan politik.

Sebagaimana dikemukakan Ebelin (dalam Erdogan, 1997) bahwa salah satu indikator dari adanya politisasi adalah ketika muncul kecenderungan untuk membuat semua pertanyaan menjadi pertanyaan politik (making all questions political questions). Mengingat salah satu hak yang dimiliki DPR adalah adalah hak untuk bertanya, maka adalah hal yang wajar ketika DPR mengajukan banyak pertanyaan kepada pemerintah ihwal substansi Rancangan Undang-Undang (RUU) Keamanan Nasional. Pertanyaan-pertanyaan yang diajukan oleh anggota DPR kepada pemerintah dalam pembahasan RUU Keamanan Nasional merupakan pertanyaan yang kemudian dapat dikatakan sebagai pertanyaan politik. Hal itu mengingat DPR selain disebut sebagai lembaga legislatif juga disebut sebagai lembaga politik yang terdiri dari beberapa kelompok atau fraksi partai politik. Kecendrungan politisasi kebijakan akan selalu muncul manakala terjadi proses pembahasan Rancangan UndangUndang antara DPR dengan pemerintah. Hal ini terlihat dari pertanyaan-pertanyaan yang diajukan DPR kepada pemerintah, yang dapat dikategorikan sebagai pertanyaan politik.

Pertanyaan politik tersebut juga dapat dimaksudkan manakala pertanyaan-pertanyaan itu digunakan oleh DPR untuk mengawasi dan mengimbangi kekuasaan pemerintah. Hal ini disebabkan RUU Keamanan Nasional merupakan hasil inisiatif pemerintah. Dengan demikian DPR berupaya untuk mengawasi substansi RUU Keamanan Nasional melalui pertanyaan-pertanyaan politik agar tercipta sebuah kebijakan yang tidak cenderung berat sebelah. Menurut seorang informan yang merupakan anggota Komisi III DPR (wawancara 9 April 2013), diketahui bahwa ada kecenderungan RUU Keamanan Nasional dapat dimanfaatkan untuk memperkuat kekuasaan pemerintah (eksekutif). Hal tersebut diatur dari adanya penetapan kondisi darurat sipil dan militer. Karenanya, DPR memberikan pertanyaan-pertanyaan politik dalam rangka proses pengawasan kebijakan.

Begitu pun halnya dari hasil pengamatan yang dilakukan dalam peneliti bahwa dalam pertanyaan-pertanyaan yang diajukan anggota DPR kepada pemerintah, terdapat beberapa pertanyaan kritis yang menyikapi beberapa pasal yang dianggap bertentangan dengan nilai-nilai demokrasi, kebebasan, dan perlindungan HAM. Di antara beberapa pasal tersebut adalah Pasal 14 ayat 1 yang menyatakan status darurat militer diberlakukan jika ada kerusuhan sosial. Pasal 17 ayat 4 menyatakan ancaman potensial dan aktual ditentukan dan diatur oleh Peraturan Pemerintah. Pasal 22 ayat 1 masih tetap menggunakan penyelenggaraan Kamnas melibatkan peran aktif intelijen negara. Pasal 27 ayat 1 menyatakan Panglima TNI dapat menetapkan kebijakan operasi dan strategi militer berdasarkan kebijakan dan strategi kebijakan penyelenggara Kamnas.

Rancangan Undang-Undang Keamanan Nasional merupakan rancangan kebijakan yang belakangan ini memang menjadi objek pembahasan di kalangan pemerintah (khususnya Kementerian Pertahanan), Dewan Perwakilan Rakyat (DPR) dan beberapa kalangan masyarakat sipil yang tergabung dalam Non Government Organization (NGO) bidang pertahanan dan keamanan. Hal tersebut disebabkan adanya perdebatan substansi beberapa pasal yang terdapat dalam RUU Keamanan Nasional yang sebagaimana telah dikemukakan bertentangan dengan prinsip-prinsip kebebasan serta perlindungan hak asasi manusia (HAM).

Terkait dengan kalangan LSM/NGO menyikapi pertanyaan-pertanyaan yang muncul dalam pembahasan RUU Keamanan Nasional, seorang informan (hasil wawancara dengan peneliti Lesperssi, 10 April 2013) menilai "Pembahasan RUU Keamanan Nasional di DPR menjadi hal yang menarik untuk diperhatikan karena di dalamnya terdapat pertanyaan-pertanyaan kritis, dan argumentasi- 
argumentasi yang menyangkut substansi dari pada RUU Keamanan Nasional. Sejauh ini pertanyaanpertanyaan DPR kepada pemerintah menurut saya dapat menekan pemerintah untuk merumuskan sebuah kebijakan yang memang tidak bertentangan dengan prinsip dan nilai demokrasi.” Pernyataan tersebut mengindikasikan bahwa sejauh ini pertanyaan-pertanyaan politik yang diajukan DPR kepada pemerintah masih dalam batas kewajaran karena hal tersebut merupakan wewenang DPR sebagai lembaga perwakilan rakyat.

Selain indikator pertanyaan politik, menurut Ebelin (dalam Erdogan, 1997) masalah isu-isu politik (all issues political issues) merupakan salah satu indikator lainnya yang dapat digunakan untuk menganalisis tentang politisasi. Isu adalah suatu peristiwa atau kejadian yang dapat diperkirakan terjadi atau tidak terjadi pada masa mendatang, termasuk dalam bidang sosial, politik, dan hukum. Dalam proses perumusan sebuah kebijakan, isu yang berkembang di masyarakat merupakan hal yang paling penting bagi seorang anggota legislatif, karena dengannya anggota DPR dapat menyerap dan menghimpun serta menindaklanjuti kebenaran dari isu tersebut (wawancara dengan Anggota Komisi III DPR RI, 9 April 2013).

Ketika sebuah isu menjadi perhatian anggota legislatif (DPR), muncul kemungkinan bahwa isu tersebut akan menjadi sebuah isu politik. Para anggota legislatif dapat menggunakan kekuasaannya untuk mengklarifikasi, mempertanyakan, dan memperdebatkan isu tersebut untuk kepentingan politik. Umumnya sebelum sebuah isu menjadi isu politik, isu yang didapatkan anggota legislatif dari konstituen atau dari masyarakat pada umumnya akan dibawa ke rapat fraksi untuk diputuskan apakah isu tersebut hendak diperjuangkan atau tidak. Ketika isu tersebut ditetapkan akan diperjuangkan, maka di sanalah isu tersebut menjadi sebuah isu politik.

Terkait dengan isu politik dalam pembahasan RUU Keamanan Nasional, masing masing fraksi partai politik memiliki isu yang akan diperjuangkan ataupun diperdebatkan dalam rapat pembahasan Rancangan Undang-Undang Keamanan Nasional. Berdasarkan keterangan yang didapatkan bahwa salah satu isu yang muncul dan menjadi perhatian adalah RUU Keamanan Nasional dianggap bisa mengancam hak asasi manusia (HAM) dan sistem demokrasi Indonesia yang mulai tumbuh. Lebih lanjut, menurut informasi dari wawancara dengan peneliti Lesperssi dan Anggota Komisi III DPR, salah satu yang dikhawatirkan bahwa RUU Kemanan Nasional memberikan wewenang kepada presiden untuk mengerahkan TNI dalam status tertib sipil tanpa melalui pertimbangan Parlemen (DPR) dalam menghadapi ancaman keamanan nasional. Jika wewenang yang diberikan kepada Presiden seperti hal dimaksud, sebenarnya aturan itu bertentangan dengan peraturan perundangundangan yang lain. Sebagai contoh, Undang-Undang No. 34 Tahun 2004 tentang Tentara Nasional Indonesia, yang dalam Pasal 7 ayat 3 jo Penjelasan Pasal 5, bahwa pengerahan kekuatan TNI harus didasarkan pada keputusan politik negara. Artinya, pengerahan kekuatan TNI harus melalui proses pertimbangan DPR.

Berbagai kalangan di DPR (berdasarkan wawancara dengan Anggota Komisi III DPR RI, 9 April 2013) juga mengkhawatirkan sekiranya RUU Keamanan Nasional disahkan oleh DPR, maka akan ada pasal-pasal karet yang dapat dipakai penguasa untuk mengganjal para lawan politiknya. Hal ini tentunya menunjukkan Rancangan Undang-Undang Keamanan Nasional masih memiliki banyak isu krusial yang penting untuk dibahas secara mendalam agar tidak memunculkan permasalahan baru pada masa yang akan datang, ataupun untuk menghindari terjadinya pola-pola pelaksanaan pemerintahan ketika rezim orde baru berkuasa.

Hingga saat ini masih terdapat beberapa partai politik yang enggan untuk memuluskan pengesahan RUU Keamanan Nasional, di antaranya yaitu Partai Persatuan Pembangunan (PPP), Partai Keadilan Sejahtera (PKS), Partai Demokrasi Indonesia-Perjuangan (PDI-P), Partai Golkar, dan Partai Hanura. Sedangkan partai yang dengan tegas mendukung pengesahan RUU Keamanan Nasional adalah Partai Demokrat. Namun seperti dijelaskan oleh seorang informan (wawancara dengan Anggota Komisi III DPR RI, 9 April 2013), posisi penolakan partai akan dapat berubah jika berbagai 
isu yang muncul dalam pembahasan RUU Keamanan Nasional telah ditanggapi dengan baik oleh pemerintah, dan beberapa pasal diperbaiki dan disesuaikan dengan aspirasi rakyat. Dari hal yang dikemukakan informan dan berdasarkan pengamatan yang telah dilakukan, maka peneliti menganggap isu politik yang dikemukakan oleh sebagian anggota DPR merupakan isu yang penting untuk diajukan dalam proses perumusan kebijakan keamanan nasional.

Untuk menganalisis bagaimana politisasi, perlu dilihat pula indikator semua nilai menjadi nilai politik (all values political values) (Ebelin dalam Erdogan, 1997). Nilai merupakan sesuatu yang menunjukkan kualitas atas suatu hal, nilai terkadang bersifat abstrak dan menyangkut etika, baik atau buruk. Dalam pembahasan Rancangan Undang-Undang Keamanan Nasional ada beberapa nilai yang diperjuangkan agar tidak dilanggar oleh pemerintah sebagai penyelenggara kekuasaan negara, yaitu nilai demokrasi dan nilai Hak Asasi Manusia (HAM) yang harus dilindungi.

Konsep demokrasi memiliki nilai bahwa warga negara adalah pemegang dan penentu kekuasaan pemerintahan sebab pemerintah dipilih oleh rakyat untuk menjalankan kepentingan rakyat. Sedangan HAM merupakan sebuah nilai universal yang mengakui bahwa manusia memiliki kemerdekaan dan kebebasan dalam menjalankan kehidupannya, termasuk bebas dari tekanan-tekanan politik pihak yang berkuasa. Berbicara tentang all values political values, maka nilai-nilai tersebut dapat menjadi sebuah nilai politik manakala dibahas secara bersama-sama oleh lembaga-lembaga politik, seperti partai politik, Dewan Perwakilan Rakyat (DPR), dan lembaga swadaya masyarakat (LSM).

Sebagaimana telah diamati, beberapa partai politik di DPR dan juga beberapa LSM yang memiliki fokus terhadap reformasi bidang pertahanan dan keamanan mempertanyakan dan memperdebatkan substansi dari Rancangan Undang-Undang Keamanan Nasional. Rancangan kebijakan ini dianggap tidak melindungi nilai-nilai Hak Asasi Manusia dan dapat melanggar nilai-nilai demokrasi yang masih dibangun. Hal ini terlihat dari adanya pengaturan yang sepihak tentang darurat militer dan tertib sipil, serta masih terlalu dominannya peran militer dalam RUU Keamanan Nasional.

Beberapa informan bahkan menyebutkan bahwa substansi RUU Kamnas dapat menjadi alat untuk menghambat proses demokratisasi dan kebebasan warga negara. Itu setidaknya tampak dalam Pasal 17 yang menyebutkan bahwa ancaman keamanan nasional di segala aspek kehidupan dikelompokan ke dalam ancaman militer, ancaman bersenjata, dan ancaman tidak bersenjata. Definisi itu bermakna bahwa siapa saja, yang kemudian menentang kebijakan pemerintah kemudian dapat dikategorikan sebagai orang yang mengancaman keamanan nasional, terlepas orang tersebut bersenjata ataupun tidak.

Kekhawatiran terhadap substansi RUU Keamanan Nasional bukanlah tanpa alasan sebab bangsa ini memiliki pengalaman getir dalam penegakan nilai-nilai HAM dan demokratisasi. Potret buram selama 32 tahun kekuasaan Orde Baru (Orba) telah menghadirkan beragam tragedi penculikan dan pemberangusan, demi dan atas nama stabilitas keamanan nasional. Istilah-istilah mengerikan yang oleh Michel Foucault (1984) disebut sebagai refleksi dari "dominasi kekuasaan" bermunculan, mulai dari penembak misterius, Komkamtib, makar, hingga subversif.

Hal yang diperjuangkan oleh kalangan anggota legislatif dan juga LSM terkait dengan perlu diperhatikannya nilai-nilai HAM dan demokrasi dalam substansi RUU Keamanan Nasional, maka nilai itu telah menjadi sebuah nilai politik. Kalangan LSM dan partai politik telah menggunakan nilai tersebut untuk menekan pemerintah sehingga pemerintah mau melakukan dialog dan diskusi guna memerhatikan dan mendengarkan pandangan politik mereka terkait pembahasan RUU Keamanan Nasional. Beberapa anggota DPR dan LSM menyatakan bahwa mereka tidak ingin gagal menginput kandungan nilai-nilai HAM dalam RUU Keamanan Nasional (wawancara dengan peneliti Lesperssi dan Anggota Komisi III DPR). Peneliti menilai hal yang sudah dilakukan sebagian kalangan LSM dan beberapa partai politik di DPR dalam menjadikan sebuah nilai menjadi nilai politik masih dalam hal 
yang dianggap wajar, bahkan diperlukan, karena mereka memperjuangkan nilai-nilai yang sangat mendasar dan perlu dilindungi.

Indikator terakhir dari politisasi adalah ketika semua keputusan yang diambil dari sebuah kebijakan menjadi keputusan politik (all decisions political decisions) (Ebelin dalam Erdogan, 1997). Terkait dengan indikator ini peneliti mencoba mengutip pula pendapat Joyce Mitchell (dalam Budiardjo, 2009:20) yang mengatakan: "Politik adalah pengambilan keputusan kolektif atau membuat kebijakan umum untuk masyarakat seluruhnya." Sebuah kebijakan ditetapkan melalui sebuah keputusan yang disepakati bersama, dalam sebuah negara demokrasi kebijakan diputuskan bersama antara eksekutif dan legislatif dalam rangka check and balance.

Meskipun semua keputusan menjadi keputusan politik, tidak selamanya indikator ini dapat dipersepsikan negatif ketika membicarakan tentang politisasi kebijakan. Argumentasi bahwa keputusan politik bukan sebuah hal yang bersifat negatif karena politik itu sudah menjadi sebuah aktivitas untuk mengambil keputusan yang menyangkut kepada kepentingan umum yang dilahirkan dalam bentuk sebuah kebijakan umum. Oleh karena itu, meskipun sebuah keputusan harus menjadi keputusan politik, jika dilandasi untuk kepentingan umum tidak ada persoalan atas keputusan politik tersebut. Bahkan ketika berbicara tentang mekanisme pengambilan keputusan yang ada, DPR mempunyai hak untuk menentukan sikap atas sebuah rancangan kebijakan.

Terkait dengan pandangan itu peneliti berdasarkan hasil wawancara dengan informan dari Lembaga Studi Pertahanan dan Studi Strategis Indonesia (Lesperssi) dan anggota DPR, mendapatkan sebuah argumentasi yang menguatkan bahwa keputusan politik tidak selamanya memiliki kecenderungan negatif manakala keputusan itu diambil atas dasar kesepakatan bersama dan untuk kebaikan masyarakat. Dalam pembahasan RUU Keamanan Nasional, pemerintah tidak bisa secara sepihak membuat keputusan untuk mengesahkan kebijakan ini sebelum DPR juga sepakat untuk menyetujuinya. Ada mekanisme yang sudah di atur dalam UUD 1945 dan itu harus dijalankan (wawancara dengan Anggota Komisi III DPR RI, 9 April 2013).

Selama ini pengambilan keputusan politik dalam RUU Keamanan Nasional memang seolah mengalami jalan buntu. Pemerintah dengan sebagian besar fraksi di DPR belum bisa menyepakati beberapa pasal yang ada dalam rancangan kebijakan tersebut. Bahkan informan dari DPR tersebut mengakui di dalam DPR sendiri ada dinamika politik yang terjadi sehingga mempengaruhi keputusan politik itu sendiri. Seperti halnya Partai Demokrat yang mendukung agar RUU Kemanan Nasional untuk segera disahkan dengan partai-partai lainnya yang lebih menginginkan agar pemerintah berupaya memperbaiki terlebih dahulu draft RUU Keamanan Nasional (wawancara dengan Anggota Komisi III DPR RI, 9 April 2013).

Peneliti memperoleh pandangan yang tidak jauh berbeda dari dua informan lainnya, yang merupakan pengamat dan peneliti pertahanan dari Lesperssi, "Bahwa keputusan politik DPR untuk tidak mengesahkan RUU Keamanan Nasional pada saat ini adalah tepat, di saat substansi yang ada dalam rancangan kebijakan itu masih belum berpihak pada agenda reformasi dan demokrasi.” Dari kedua pandangan tersebut, peneliti masih melihat adanya alasan yang argumentatif dan rasional terkait keputusan politik yang diambil oleh DPR.

Setiap negara memiliki sistem yang berbeda dalam hal pengambilan keputusan dan masingmasing mempunyai landasan serta argumentasinya yang berbeda, masing-masing negara dengan sistemnya meyakini bahwa keputusan politik yang mereka buat dengan sistemnya dapat memengaruhi kualitas dan tingkat keluasan dari kebijakan dalam menyentuh kepentingan masyarakat. Akan tetapi, bagi sebuah negara demokrasi ada berbagai tantangan bagi pihak-pihak yang mengambil keputusan dan melahirkan kebijakan umum, baik sebelum kebijakan itu diputuskan hingga pasca kebijakan itu diputuskan. 
Oleh karena itu, dalam negara yang demokratis sebuah kebijakan perlu dirumuskan secara matang melalui mekanisme diskursus publik yang memungkinkan adanya ruang bagi pertanyaan dan perdebatan. Adanya perdebatan dalam proses pengambilan keputusan politik RUU Keamanan Nasional merupakan hal yang lumrah terjadi, terlebih jika perdebatan itu menyangkut hal yang substansial dan menyentuh kepentingan seluruh masyarakat. Dalam kondisi dimana keputusan politik tidak tercapai dalam pengesahan RUU Keamanan Nasional, maka peneliti melihat hal itu masih dalam batas kewajaran sebab substansi yang ada dalam RUU Kamnas tidak hanya dinilai kurang berpihak pada proses demokrasi oleh DPR tetapi juga oleh beberapa kelompok masyarakat lainnya.

\section{SIMPULAN}

Politisasi kebijakan menjadi sebuah persoalan yang muncul dalam perumusan kebijakan RUU Keamanan Nasional, sebab hingga saat ini terjadi tarik ulur yang berujung pada belum disahkannya RUU Keamanan Nasional menjadi undang-undang yang mampu menaungi kebijakan-kebijakan lainnya di sektor pertahanan dan keamanan. Beberapa kalangan menilai politisasi kebijakan atas RUU Keamanan Nasional sebagai suatu hal yang wajar mengingat pembahasan dan pengesahan kebijakan tidak dapat dilepaskan dari dua lembaga tinggi negara, yaitu eksekutif dan legislatif (DPR). Baik eksekutif dan legislatif saat ini memiliki pandangan yang berbeda atas RUU Keamanan Nasional, bahkan di internal DPR pun terjadi pandangan yang berbeda antar partai politik.

Sejauh ini politisasi kebijakan RUU Keamanan Nasional masih terlihat dalam batas kewajaran bila dilihat dari indikator pertanyaan politik, masalah isu-isu politik, nilai politik, dan keputusan politik. Dari aspek membuat semua pertanyaan menjadi pertanyaan politik, DPR memberikan pertanyaan politik dalam rangka proses pengawasan kebijakan. Sebagai wakil rakyat, DPR mempertanyakan kepada pemerintah terkait keraguan dan kekhawatiran masyarakat. Dari aspek isuisu politik, isu yang muncul dan menjadi perhatian adalah RUU Kamnas dianggap bisa mengancam HAM dan sistem demokrasi. Berdasarkan aspek semua nilai menjadi nilai politik, kalangan LSM dan beberapa partai politik di DPR memperjuangkan nilai-nilai HAM dan demokrasi yang sangat mendasar dan perlu dilindungi. Sedangkan dari aspek keputusan politik, keputusan politik DPR untuk tidak mengesahkan RUU Kamnas adalah karena rancangan kebijakan itu belum berpihak pada agenda reformasi dan demokrasi.

Berdasarkan simpulan tersebut di atas maka saran akademis penelitian ini adalah agar pemerintah maupun DPR memperhatikan indikator dari politisasi kebijakan, seperti pertanyaan politik, masalah isu-isu politik, nilai politik, dan keputusan politik. Sedangkan saran praktis penelitian ini adalah agar dibangun pola komunikasi yang baik antara pemerintah dengan DPR, dan antara keduanya dengan rakyat dalam mendiskusikan kebijakan RUU Keamanan Nasional.

\section{DAFTAR PUSTAKA}

Anwar, D. F. (2004). Sasaran Sishankamneg 5-10 tahun Mendatang. Dalam Indria Samego (ed.). Sistem Pertahanan-Keamanan Negara: Analisis Potensi dan Problem. Jakarta: The Habibie Center.

Bakrie, C. R. (2007). Pertahanan Negara dan Postur TNI Ideal. Jakarta: Obor Indonesia.

Budiardjo, M. (2009). Dasar-dasar Ilmu Politik. Jakarta: Gramedia Pustaka Utama. 
Erdogan, E. (2004). An Exploration of the Politicization Concept of Putnam: Determinants of Attitudes of Citizens about Foreign Policies. Turki: Bogazici University.

Fuad, H. (2012, 16 Jan). Beleid Keamanan Nasional; RUU Kamnas Masih Menjadi Kontroversi. Diakses 13 Maret 2012 dari http://nasional.kontan.co.id/news/ruu-kamnas-masih-menjadikontroversi.

Islamy, M. I. (2004). Prinsip-prinsip Perumusan Kebijakan Negara. Jakarta: Sinar Grafika.

Joyce, P. (2008). Politics (teach yourself). London: Hodder Headline, Ltd.

Kamus Besar Bahasa Indonesia. (2014). Politisasi. Diakses dari http://kbbi.web.id/politisasi.

La Ode, M. D. (2006). Peran Militer dalam Ketahanan Nasional; Studi Kasus Bidang Hankam di Indonesia Tahun 1967 - 2000. Jakarta: Pustaka Sinar Harapan.

Martini, R. (2010). Politisasi birokrasi di Indonesia. Politika Jurnal Ilmu Politik, 1(1). Universitas Diponegoro.

Merkl, P. H. (1967). Continuity and Change. New York: Harper and Row.

Nogi, H., dkk., (2004). Hukum dan Kebijakan Publik. Yogyakarta: YPAPI.

Nugroho D., Riant. (2004). Kebijakan Publik (Formulasi, Implementasi, dan Evaluasi). Jakarta: Elex Media Komputindo.

Peters, B. G., \& Pierre, J. (2004). Politicization of the Civil Service in Comparative Perspective. London: Routledge.

Prihatono, T. H., dkk. (2007). Keamanan Nasional: Kebutuhan Membangun Perspektif Integratif Versus Pembiaran Politik Kebijakan. Jakarta: ProPatria Institute.

Sadono, B. (2010). Politisasi hukum media di Indonesia. Jurnal Semai Komunikasi, 1(1). Universitas Semarang.

Surbakti, R. (2010). Memahami Ilmu Politik. Jakarta: Gramedia.

Suryohadiprojo, S. (2005). Si Vis Pacem Para Belum; Membangun Pertahanan Negara yang Modern dan Efektif. Jakarta: Gramedia Pustaka Utama.

Wahab, S. A. (2004). Analisis Kebijaksanaan dari Formulasi ke Implementasi Kebijaksanaan Negara. Jakarta: Bumi Aksara.

Winarno, B. (2008). Teori dan Proses Kebijakan Publik. Yogyakarta : Penerbit Media Pressindo. 